\title{
THE EFFECTS OF TEMPERATURE ON THE LEACHING BEHAVIOR OF CEMENT WASTE FORMS - THE CEMENT/SODIUM SULFATE SYSTEM*
}

\author{
M. Fuhrmann, R. Pietrzak, J. Heiser, E.M. Franz and P. Colombo
}

October 1989

\author{
NUCLEAR WASTE RESEARCH GROUP \\ RADIOLOGICAL SCIENCES DIVISION \\ DEPARTMENT OF NUCLEAR ENERGY \\ BROOKHAVEN NATIONAL LABORATORY \\ UPTON, NEW YORK 11973
}

\begin{abstract}
DISCLAIMER
This report was prepared as an account of work sponsored by an agency of the United States Government. Neither the United States Government nor any agency thereof, nor any of their employees, makes any warranty, express or implied, or assumes any legal liability or responsibility for the accuracy, completeness, or usefulness of any information, apparatus, product, or process disclosed, or represents that its use would not infringe privately owned rights. Reference herein to any specific commercial product, process, or service by trade name, trademark, manufacturer, or otherwise does not necessarily constitute or imply its endorsement, recommendation, or favoring by the United States Government or any agency thereof. The views and opinions of authors expressed herein do not necessarily state or reflect those of the Uniteó States Government or any agency thereof.

Prepared for the

NATIONAL LOW-LEVEL WASTE MANAGEMENT PROGRAM UNDER CONTR ACT NO. DE-AC0?-76CH00016 WITH THE UNITED STATES DEPARTMENT OF ENERGY
\end{abstract}

*To be presented at the Material Research Society 1989 Fall Meeting in Boston. Massachusetts. Vovember 27-December 2, 1989. 
MARK FLHRMANN, RICHARD PIETRZAK, JOHN HEISER III, EENA-MAI FR.ANZ AND PEIER COLOMBO

Vuclear Waste Research Group, Brookhaven National Laboratory. Upton, NY, 11973.

\section{ABSTRACT}

The leaching mechanisms of simulated low-level radioactive waste forms are being determined as support for development of an accelerated leach test. Two approaches are being used: (1) comparisons of leaching data with results of a model that describes diffusion trom a tinite sylinder, and (2) observation of the leaching process at temperatures between $20^{\circ} \mathrm{C}$ and $65^{\circ} \mathrm{C}$. To provide results that can be used for modeling, leaching at elevated temperatures must change neither the leaching mechanism nor the structural controls of leaching such as the porosity. Releases of ${ }^{137} \mathrm{Cs},{ }^{35} \mathrm{Sr}$, calcium, sodium and potassium from portland cement containing sodium sulfate. as a simulated evaporator sludge, have been determined under a variety of experimental conditions. Data trom the leach tests were compared to model results for diffusion irom the ïnite eylinder. While most leaching appears to be diffusion controlled, notable exceptions occur. For all samples activation energies ranging between 6 and $11 \mathrm{~K}$ sal/mole have been calculated irom the reiationship of the effective diffusion coetficient to increasing temperature. close to the expected value of $5 \mathrm{Ka} / /$ mole tor diffusion.

\section{INTRODUCTION}

The leaching behavior of cement-based. simulated low-level waste forms was studied at temperatures between $20^{\circ} \mathrm{C}$ and $6.5 \mathrm{C}$ as support tor the development of an accelerated leash test. In previous investigations $[1,2,3,4,5]$ a variety of factors, such as elevated temperature and increased leachant volume, were examined for their ability to accelerate leaching. Initially, they were studied indiviciually, later the most usetul factors were combined to obtain greater release rates.

From this work an accelerated leach test method [6] was developed for low-level radioactive waste forms. The leach test method was designed to minimize experimental artitacts that zould be misinterpreted as release mechanisms such as effects of increased ionic concentrations in the leachate. This is particularly important when the data is used for mechanistic interpretations and long-term extrapolations. A computer program associated with the accelerated leach test allows the user to test experimental rosults against a model for diffusion from a finite cylinder [7.8]. If the model and the data iit within preset criteria then the diffusion model can be used to make projections of releases. Leaching data were analyzed to assess: 1) whether the model for diffusion from a tinite cylinder describes leaching from cement based waste forms and I) whether alevated temperature provides a predictable increase in leach rate. In this paper some of the experimental and modeling work used to validate the test method are presented. Only the work on portland cement containing sodium sulfate is presented here. Results of similar studies with portland semeat alone and portland cement containing incinerator ash will be published separateIy.

\section{METHODS}

Releases of ${ }^{137} \mathrm{Cs},{ }^{35} \mathrm{Sr}$, calcium. potassium and sodium were investigated for portland iype l eament plus $5 \mathrm{w} \mathrm{r}^{\mathrm{t} \%} \mathrm{~h}$ sodium suliate salt. This formulation represents a typical iow-level waste torm

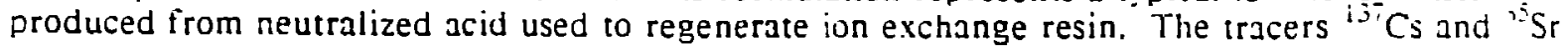
were added during production of the samples. Details of composition are given elsewhere [5]. 
The leach test [0] is a semi-dynamic test in which the leachate is replaced periodically aftar intervals ot static leaching. Specimens are leached in individual containers containing a rat io it $100 \mathrm{~cm}$ berween the volume of the leachant and the external geometric surface area of the splicimen. The keanant is distilled water with a conductance of less than 5 Imhos $\mathrm{cm}$. Spccimens ..: wsually testet in triplicate to determine the variation in leaching. Experiments run at elevald temperatures were conducted in an environmental chamber with strict temperature controls. The results of the leach tests are expressed as cumulative fraction leached (CFL) or as an ef fective diffusion coefficient $\left(D_{e}\right)$, to facilitate alternative methods of treating the data.

A model tor bulk diffusion from a finite cylinder is used as a guide to determine if diffusion is the rate controlling transport mechanism during leaching. A value for the optimum De value is obtained by tirst astimating De using the semi-infinite medium approach. Then iterations are pertormed with the finite cylinder model to obtain the $D_{\text {. }}$ balue that gives the lowest sum of the residuals for the entire set of data.

The goodness-of - $f$ it between the data and the model result is evaluated by expressing the : of the residuals as a percentage of the maximum CFL of the experimental data, $E_{R}$. If $E_{R} \leq 0.5$ then it is taken to mean that diffusion is the dominant leaching mechanism. Figure 1 show's the relationship between the data from an experiment and the diffusion model when $E_{k}=0 . j l$.

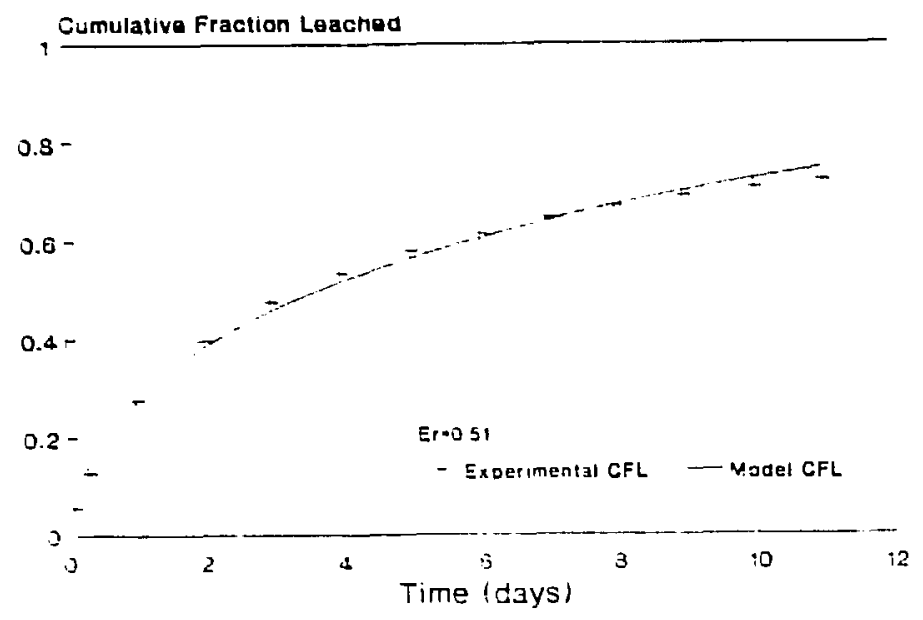

Figure 1. Experimental data are compared to the diffusion model when $E_{?}=0.51$. These data are tor ${ }^{137} \mathrm{Cs}$ leached from a cement/sodium sultate sample at $50^{\circ} \mathrm{C}$.

\section{RESULTS AND DISCLSSION}

Table I contains $D_{L}$ and $E_{R}$ values for various elements leached from triplicate samples of sement containing $5 \mathrm{wt}$ " of the $V_{a}$ is from the sulfate salt and the ${ }^{137} \mathrm{Cs}$ and ${ }^{55} \mathrm{Sr}$ were added as tracers.

Releases of $N a$ generally have values of $E_{R}$ that are close to or less than $0.50 \%$ indicating that diffusion controls releases at all temperatures. The exceptions are two of the three s:mmples leached $a t+j^{\circ} \mathrm{C}$. Leaching of $\mathrm{K}$ gives more scattered results with the $45^{\circ} \mathrm{C}$ samples having ispecially large errors. All of the Ca results are greater ihan $0.50 \%$ indicating that ditfusion dhes: not control the release rate of Ca. Plots of CFL versus time for Ca (figure 2) are more line:ar thi:n the diffusion curve, illustrating that solubility limits are the leach rate controlling factor. Maximum concentrations of $\mathrm{C}_{3}$ in the leachate are $4.2-4.8 \mathrm{mg} / \mathrm{l}\left(\right.$ at $20^{\circ} \mathrm{C}$ ) which is close to the solubility of $6 \mathrm{mg} / 1$ for salcium carbonate (this is much lower than the solublity limits of any other major compounds that could be present). Leaching of ${ }^{35} \mathrm{Sr}$ is diffusion controlled berween $=0^{\circ} \mathrm{C}$ and $50^{\circ} \mathrm{C}$, but at higher temperatures it was not. 
TABLE I

Effective Diffusion Coefficients For Cement Containing Sodium Sulfate

Sample A

Sample B

Sample C

Sodium
$D_{e}\left(\mathrm{~cm}^{2} ; \mathrm{s}\right)$
$E_{Q}(\%)$
$\mathrm{D}_{\mathrm{e}}\left(\mathrm{cm}^{2} / \mathrm{s}\right)$
$E_{R}(\%)$
$\mathrm{D}_{\mathrm{e}}\left(\mathrm{cm}^{2} ; \mathrm{s}\right)$
$E_{R}\left({ }^{(\prime 0)}\right.$

$\begin{array}{ll}20^{\circ} \mathrm{C} & 2.17 \times 10^{-3} \\ 35^{\circ} \mathrm{C} & 7.99 \times 10^{-8} \\ 45^{\circ} \mathrm{C} & 1.47 \times 10^{-7} \\ 50^{\circ} \mathrm{C} & 1.26 \times 10^{-7} \\ 55^{\circ} \mathrm{C} & 1.72 \times 10^{-7} \\ 65^{\circ} \mathrm{C} & 3.34 \times 10^{-7}\end{array}$

0.10
0.02
1.26
0.04
0.08
0.55

$3.04 \times 10^{-8}$

0.16

$4.88 \times 10^{-8}$

0.30

$1.72 \times 10^{-7}$

1.26

$1.47 \times 10^{-7}$

0.19

$2.00 \times 10^{-7}$

$3.51 \times 10^{-7}$

0.53

0.24

$2.92 \times 10^{-3}$

0.01

$7.43 \times 10^{-6}$

0.07

$9.58 \times 10^{-3}$

0.01

$1.56 \times 10^{-7}$

0.06

$1.74 \times 10^{-7}$

0.02

$3.51 \times 10^{-7}$

0.07

Potassium

$20^{\circ} \mathrm{C}$
$35^{\circ} \mathrm{C}$
$45^{\circ} \mathrm{C}$
$50^{\circ} \mathrm{C}$
$55^{\circ} \mathrm{C}$
$65^{\circ} \mathrm{C}$

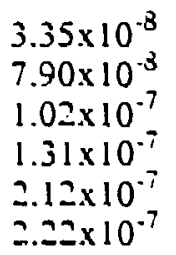

0.04

1.07

5.94

0.30

0.05

0.97

$3.95 \times 10^{-8}$

$4.98 \times 10^{-5}$

$1.22 \times 10^{-7}$

$1.63 \times 10^{-7}$

$2.05 \times 10^{-7}$

$2.36 \times 10^{-7}$

0.03

0.02

6.82

0.60

0.04

0.87

$3.34 \times 10^{-8}$

$7.48 \times 10^{-3}$

0.11

$7.78 \times 10^{-8}$

1.00

$1.57 \times 10^{-7}$

1.20

$2.11 \times 10^{-7}$

0.35

$2.91 \times 10^{-7}$

0.06

1.18

Calcium

$20^{\circ} \mathrm{C}$

$5.56 \times 10^{-11}$

$35^{\circ} \mathrm{C}$

$3.83 \times 10^{-\mathrm{i} 0}$

$5.89 \times 10^{-11}$

4.41

$3.73 \times 10^{-10}$

0.74

$45^{\circ} \mathrm{C}$

1.97

$50^{\circ} \mathrm{C}$

$+.92 \times 10^{-10}$

0.76

$55^{\circ} \mathrm{C}$

$3.65 \times 10^{-10}$

3.67

$65^{\circ} \mathrm{C}$

$8.86 \times 10^{-10}$

0.53

$2.62 \times 10^{-10}$
$3.95 \times 10^{-10}$

3.86

1.10

1.16

$5.66 \times 10^{-10}$

0.67

$3.16 \times 10^{-10}$

3.44

$3.89 \times 10^{-10}$

0.39

$1.24 \times 10^{-7}$

$1.84 \times 10^{-7}$

0.52

0.55

$1.53 \times 10^{-7}$

0.85

$1.72 \times 10^{-7}$

0.51

$50^{\circ} \mathrm{C}$

$55^{\circ} \mathrm{C}$

$2.94 \times 10^{-7}$

1.07

$65^{\circ} \mathrm{C}$

$5.26 \times 10^{-7}$

0.88

$2.16 \times 10^{-7}$

$3.06 \times 10^{-7}$

$3.79 \times 10^{-7}$

1.16

0.38

2.17

2.55

$1.22 \times 10^{-7}$

$3.38 \times 10^{-7}$

1.08

$5.62 \times 10^{-11} \quad 3.17$

$3.49 \times 10^{-10}$

0.55

$2.91 \times 10^{-\mathrm{iu}}$

2.30

$5.29 \times 10^{-10}$

0.98

$3.45 \times 10^{-10} \quad 3.91$

$8.65 \times 10^{-10}$

0.19

$2.47 \times 10^{-7}$

$2.94 \times 10^{-7}$

1.76

1.32

Strontium-85

$\begin{array}{ll}20^{\circ} \mathrm{C} & 4.41 \times 10^{-10} \\ 45^{\circ} \mathrm{C} & 1.40 \times 10^{-9} \\ 50^{\circ} \mathrm{C} & 1.01 \times 10^{-4} \\ 55^{\circ} \mathrm{C} & 1.03 \times 10^{-3} \\ 65^{\circ} \mathrm{C} & 4.00 \times 10^{-9}\end{array}$

0.05

0.06

0.02

0.69

1.44

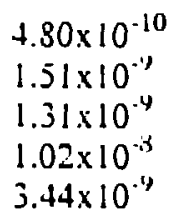

0.14

0.10

0.14

0.66

1.46

$\begin{array}{ll}4.88 \times 10^{-10} & 0.29 \\ 1.8+\times 10^{-9} & 0.20 \\ & \\ 7.76 \times 10^{-9} & 0.45 \\ 2.98 \times 10^{-9} & 1.57\end{array}$




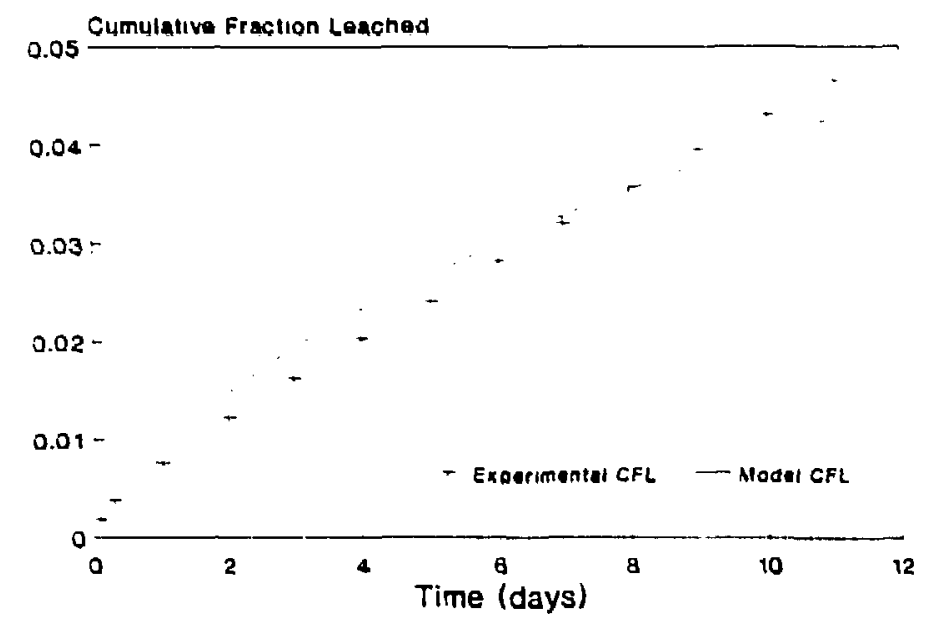

Figure 2. Releases of calcium do not fit the diffusion model. The experiment data are linear after the tirst "ew points indicating that solubility limits the concentration of $\mathrm{Ca}$ in the leachate.

Releases of ${ }^{137} \mathrm{CS}$ as indicated by the $\mathrm{E}_{R}$ values, are not diffusion controlled. The data at the end of the experiments typically fall below the model curve. An example is show: in Figure 3. Curve $A$ is the diffusion curve that represents the best fit of the model to the data, giving an $E_{R}$ value of $2.43 \%$. By adjusting the source term downward by about $12 \%$ and generating Curve $B$, the tit is improved to in $E_{R}$ of $0.37 \%$. Because the source term has been checked several times, it is certain that the original source terms are not in error. Some of the ${ }^{137} \mathrm{Cs}$ is not available for leaching because it has jeen taken into the solid phase of the sample through adsorpiion, crystal lattice substijation or some other mechanism. Portland cement has a very low sapacity to take up cesium [10]. However, earlier work in this program has shown that authigenic products, such as $\mathrm{CaCO}_{3}$, that form on the surtace of cement during leaching do have some capacicy to adsorb ${ }^{137} \mathrm{Cs}$ and inhibit the movement of dissolved species to the surface of the sample [4,11]. For these reasons the leaching mechanism of cesium (and probably porassium) can best be described by diffusion plus adsorption. For optimum results, it may be necessary for the adsorption term to "grow in" with the formation of $\mathrm{CaCO}_{3}$.

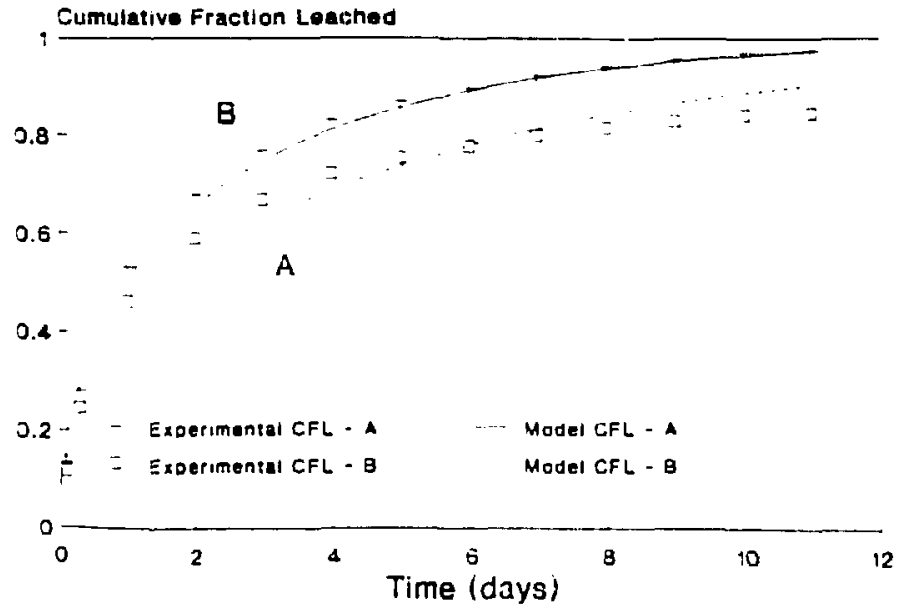

Figure 3. Comparison of C.FL curves for ${ }^{137} \mathrm{Cs}$ leached at $65 \mathrm{C}$. Curve $A$ is the untreated data. Curve $B$ is normalized by adjusting the source term downward by $12 \%$. improving the fit of the model to the data. 
If temperature changes neither the mechanism of leaching nor the structural controls on leaching, then an Arrhenius plot of the $\log$ of the leach rate as a tunction of $1, T$ (where $T$ equal: tamperature in Kelvins) wiil be linear.

Figure $t$ is an Arrhenius plot of averaged $D$. values for leaching of cement sodium sulfate amples. It shows that increasing temperature systematically increases the effective ditfusiun zuetitizients. Linear regression of the data. including all triplicates, gives correlation coetificients at shown in Table II. Also in table II are activation energies $\left(E_{a}\right)$ calculated from the slope of 16 regression lines. For waste torms containing a simulated waste that is known to react will portland cement, these correlations are acceotable. The activation energies are slightly higher than the $5 \mathrm{Kcal} / \mathrm{mole}$ expected for diffusion. This implies that the rate of increase in leaching $n$. $y$ not be predictable and will need to be determined empirically for each material tested.

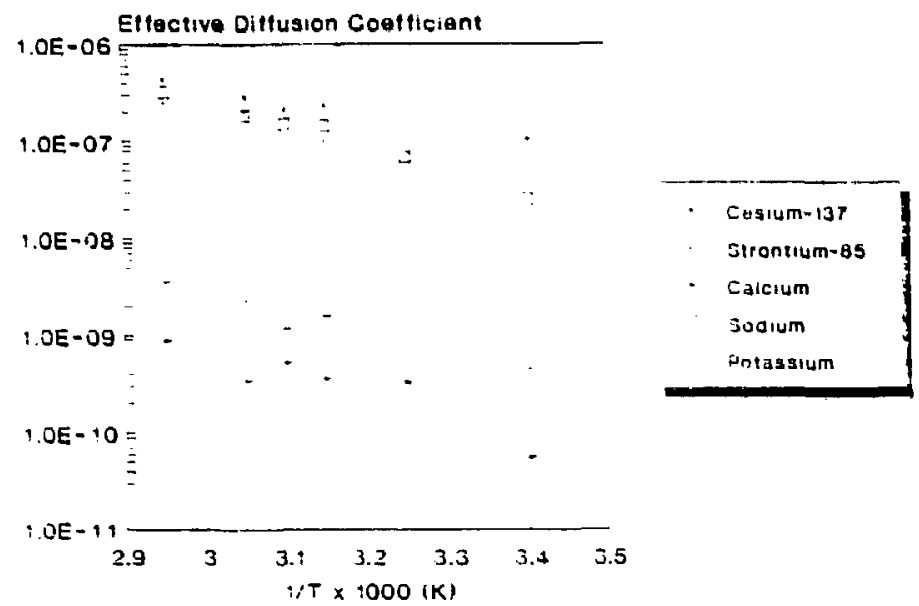

Figure 4. Arrhenius plot showing the reponse of $D_{e}$ to increasing temperaiure for each of the slements studied.

Table II

Correlation Coefficients and Activation Energies

For Cement/Sodium Sulfate Samples

\section{Element}

$\operatorname{lit}^{2} \mathrm{Cs}$

$\mathrm{Sr}$

$\mathrm{Ca}$

$\mathrm{K}$

$\therefore 3$

\section{Correlation Coefficient (r)}

0.89

0.96

0.97

0.97

0.91

\section{$E_{\mathrm{a}}$ (Kcal/mole)}

6.0

8.7

11

9.4

\section{CONCLUSIONS}

Cement waste forms containing sodium sulfate leach via three mechanisms under the experimental conditions presented in the accelerated leach test. Sodium leaches by diffusion. Calciuin releases are controlled by solubility. Potassium and cesium leach by diffusion that is modified by adsorption probably on calcium carbonate that forms on the surfaces of the waste ijrms. Strontium leaches by diffusion up to $50 \mathrm{C}$ and then is controlled by another process at iigher temperatures.

Although the leaching mechanisms of cement waste forms containing sodium sulfate are not strictly diffusion. this has little effect on the usefulness of elevated temperature tor accelerated leaching. Arrhenius plots of the elements studied indicate that increasing temperature accelerate. the leach rate. 


\section{REFERENCES}

1. Fuhrmann, M., Pietrzak, R.F., Franz, E.M., Heiser, J.H., and Colombo, P., "Optimization at the Factors that Accelerate Leaching," BNL-52204, Brookhaven Nationai Laboratory, Lpton, New York 11973, Warch 1989.

․ Dougherty, D., Pietrzak, R.F.. Fuhrmann. M., and Colombo, P.. "An Experimental Surve! ut the Factors that Affect Leaching from Low-Level Radioactive Waste Forms," BNL52125 . Brookhaven National Laboratory, Upton, New York 11973, Suptember 1988.

3. Fuhrmann, M., Pietrzak, R.F., Heiser, J., Franz, E.M., and Colombo, P., "Accelerated Lasih Test Program, Annual Report tor FY 1989," Brookhaven National Laboratory, Lipton. New York 11973, September 1989.

4. Dougherty, D.R. and Colombo, P., "Leaching Mechanisms of Solidified Low-Level Waste. The Literature Survey," BNL-51899, Brookhaven National Laboratory, Upton, New York 11973. June 1985.

5. Dougherty, D.R.. Pietrzak, R.F., Fuhrmann, M.. and Colombo. P.. "Accelerated Leach Test Program Annual Report," BNL-52042, Brookhaven National Laboratory, Upton, New York. 11973 . September 1986.

j. Fuhrmann, M., Pietrzak, R.F., Heiser. J., Franz. E.M., and Colombo, P., "Draft Acceleratel Lasch Test." Brookhaven National Laboratory, Upton, New York 11973. in press.

7. Pascatore, C. and Machiels. A.J., "Mechanistic Approach to Modeling of Nuclear Waste Form Leaching," Advances in Caramics, Vol. 8, Nuclear Waste Management '84. pages 50 s518.

8. Pescatore, C., "Improved Expressions for Modeling Diffusive, Fractional Cumulative Leaching from Finite Size Waste Forms." BNL-42405. Brookhaven National Laboratory, Lipton, New York 11973.

9. Piatrzak, R.F., Fuhrmann, M.. Franz. E.M., Heiser, J., and Colombo. P.. "Acceleraied L:2en Testing of Radionuclides trom Solidified Low-Level Waste." BNL-42121, presented ar the American Chemical Society Meeting, Dallas, Texas, April 9-14, 1989.

10. . Veilson Jr.. R. and Colombo, P.. "Waste Form Development Program," Annual Progress Report (October 1980-September 1981). BNL-51517, Brookhaven National Laboratory, Lpton, New York 11973, January 1982.

11. Fuhrmann. M. and Colombo, P., "Leaching Induced Concentration Protiles in the Solid Phase of Cement." Environmental Aspecrs of Stabilization and Solidification of Hazardous and Radioactive Wastes, AST.M STP 1033, P.L. Cote and T.M. Gilliam (editors). Americin Society for Testing and Materials, Philadelphia. PA, pp. 302-31+(1989). 